\title{
Electrochemistry of Zirconium in Molten Chlorides
}

\author{
Liang $X u^{1}$, Yanping Xiao ${ }^{3}$, Qian $X u^{2,}$ *, Qiushi Song ${ }^{1}$, Yongxiang Yang ${ }^{3,4}$ \\ ${ }^{1}$ School of Metallurgy, Northeastern University, Shenyang 110004, China \\ ${ }^{2}$ State Key Laboratory of Advanced Special Steel, Shanghai University, Shanghai 200072, China \\ ${ }^{3}$ School of Metallurgical Engineering, Anhui University of Technology, Ma'anshan 243002, China \\ ${ }^{4}$ Department of Materials Science and Engineering, Delft University of Technology, 2628 CD Delft, \\ The Netherlands \\ *E-mail: qianxu@shu.edu.cn
}

doi: $10.20964 / 2017.07 .51$

Received: 5 April 2017 / Accepted: 29 April 2017 / Published: 12 June 2017

\begin{abstract}
In this work, the electrochemical behavior of zirconium was studied on an inert molybdenum electrode at $550{ }^{\circ} \mathrm{C}$ in a $\mathrm{LiCl}-\mathrm{KCl}-\mathrm{K}_{2} \mathrm{ZrF}_{6}$ molten salt system, which is considered as an ideal electrolyte for the zirconium electrorefining process. Several transient electrochemical techniques were used such as cyclic voltammetry, chronopotentiometry, square wave voltammetry, and open circuit chronopotentiometry. The reduction of $\mathrm{Zr}$ (IV) was determined to follow a two-step mechanism of $\mathrm{Zr}$ (IV)/Zr (II) and $\mathrm{Zr}$ (II)/Zr. The diffusion coefficient of $\mathrm{Zr}$ (IV) was investigated with cyclic voltammetry and chronopotentiometry, and the results turned out to be in fair agreement from the both methods, as to be $4.26 \times 10^{-5}$ and $4.98 \times 10^{-5} \mathrm{~cm}^{2} / \mathrm{s}$, respectively. The present study aims to provide a theoretical reference for the $\mathrm{Zr}$ electrorefining process.
\end{abstract}

Keywords: redox mechanism, zirconium, molten salt, electrochemistry.

\section{FULL TEXT}

(C) 2017 The Authors. Published by ESG (www.electrochemsci.org). This article is an open access article distributed under the terms and conditions of the Creative Commons Attribution license (http://creativecommons.org/licenses/by/4.0/). 